\title{
Seasonal fluctuations in macrobenthic fauna of the Fucus belt in Kiel Fjord (western Baltic Sea)
}

\author{
K. Anders \& H. Möller \\ Institut für Meereskunde; Düsternbrooker Weg 20, D-2300 Kiel, \\ Federal Republic of Germany
}

\begin{abstract}
The macrobenthic fauna associated with Fucus at a station in the Kiel Fjord was investigated from June 1978 until June 1979. The predominant group in number as well as in biomass were gammarids. They formed, together with the isopods Idotea spp., approximately $95 \%$ of the total average annual biomass. The total dry weight of all macrobenthic animals (excl. Littorina spp.) increased from $1.9 \mathrm{~g}$ per $\mathrm{kg}$ Fucus in May to about $16 \mathrm{~g}$ in June-August, and dropped to $8.3 \mathrm{~g}$ in September. Winter average dry weight values were only about $6 \%$ of the summer values.
\end{abstract}

\section{INTRODUCTION}

The brown alga Fucus vesiculosus forms a substantial part of the seaweed community from the midwater line down to about $2 \mathrm{~m}$ depth in the Baltic Sea. Due to the lack of major rock soils in Kiel Bight, mainly individual stones lying on sandy and muddy bottom and hard substrate are colonized.

Hoffmann (1952) estimated the Fucus stocks ( $F$. vesiculosus and F. serratus) of Kiel Bight from depths of 0 to $6 \mathrm{~m}$ to be about $1.8 \mathrm{~kg}$ wet weight per $\mathrm{m}^{2}$. This corresponds to a yearly production of $0.6 \mathrm{~kg}$ per $\mathrm{m}^{2}$, assuming a regeneration period of 3 years. Seasonal and annual fluctuations of the stock are mainly determined by drift ice, wave action and water temperature.

Quantitative data on the colonization of Fucus by micro- and macrofauna were given by Boaden et al. (1975), Hagerman (1966), Knight \& Parke (1950), Ohm (1964), Segerstråle (1928, 1944), Haage \& Jansson (1970), Oertzen (1968), and Skult (1977). Haage $(1975,1976)$ conducted extensive studies near Askö in the northwestern Baltic Sea on the population development of the predominant species.

The present study focusses on the quantification of that zoobenthic biomass in the Fucus belt, which serves as food for fishes, rather than on taxonomic aspects.

\section{METHODS}

Twenty-four samples were taken between June 1978 and June 1979. Weekly sampling periods were interrupted by coastal ice layers in winter and early spring (Table 1). Sampling took place at a depth of $0.5 \mathrm{~m}$ within the outlet of Kiel Fjord (Fig. 1). The area was well protected against major wave action, produced by the predominating west winds. The bottom was a mixture of sand and mud with many single stones colonized by Fucus plants. Salinity usually ranges from 12 to $16 \times 10^{-3} \mathrm{~S}$. 
Table 1. Basic data on samples

\begin{tabular}{|c|c|c|}
\hline $\begin{array}{c}\text { Date } \\
\text { Day/Month }\end{array}$ & $\begin{array}{l}\text { Water temperature } \\
\qquad\left({ }^{\circ} \mathrm{C}\right)\end{array}$ & $\begin{array}{c}\text { Sample volume } \\
\text { (g Fucus dry weight) }\end{array}$ \\
\hline \multicolumn{3}{|l|}{1978} \\
\hline 11. 6. & 13.8 & 254 \\
\hline 18. 6. & 12.0 & 256 \\
\hline 25. 6 . & 12.0 & 338 \\
\hline 2. 7 & 13.8 & 329 \\
\hline 9. 7. & 14.2 & 310 \\
\hline 16. 7. & 15.8 & 234 \\
\hline 23. 7. & 16.6 & 211 \\
\hline 30. 7 & 21.5 & 214 \\
\hline 6. 8. & 18.3 & 154 \\
\hline 13. 8. & 18.2 & 218 \\
\hline 20. 8. & 21.3 & 263 \\
\hline 29. 8. & 16.3 & 207 \\
\hline 3. 9. & 16.0 & 211 \\
\hline 17. 9. & 14.4 & 270 \\
\hline 8. 10 . & 13.0 & 183 \\
\hline 28. 10 & 11.5 & 235 \\
\hline 22. 11. & 6.9 & 226 \\
\hline 9. 12 . & 2.5 & 155 \\
\hline \multicolumn{3}{|l|}{1979} \\
\hline 7.1 & 0.9 & 236 \\
\hline 4. 2. & 0.5 & 173 \\
\hline 10. 5. & & 185 \\
\hline 19. 5. & & 204 \\
\hline 26. 5. & & 284 \\
\hline 2. 6. & & 175 \\
\hline
\end{tabular}

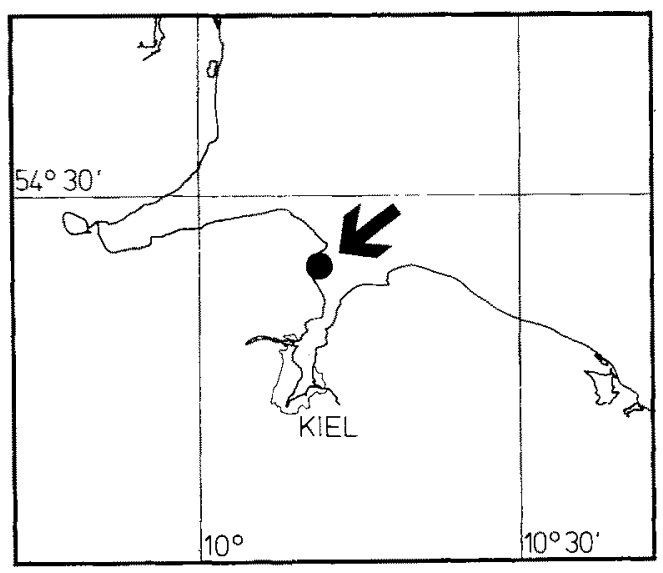

Fig. 1. Station map (in western Baltic Sea) 
Samples were taken by placing a hand net of $300 \mu \mathrm{m}$ mesh size over individual Fucus plants, closing it at the bottom and cutting off the rhizoids. Only fish and larger shore crabs were observed to escape. The samples were washed in water from the sampling place and filtered through a $300 \mu \mathrm{m}$ net. Animals clinging to the plants were loosened by short suspension in $4 \%$ formaldehyde.

The dry weights of single Fucus samples are given in Table 1. Its average value throughout the period of investigation was $230 \mathrm{~g}$. All data in the text on frequencies of benthic animals refer to $1 \mathrm{~kg}$ algae dry weight and are calculated as monthly average values.

\section{RESULTS AND DISCUSSION}

The predominant group in number as well as in weight were the gammarids, representing in summer, as well as over the whole year, an average of $60 \%$ of the total biomass (excl. Littorina spp., Table 2). Among these, Gammarus zaddachi and G. salinus were identified as the main species. In July, Gammarus spp. reached a maximum of 25400 individuals and in June a maximum biomass of $9.5 \mathrm{~g}$ dry weight (Tables 2, 3). Apparently, there is only one main reproduction phase (Fig. 3). During winter months, the population density of gammarids dropped to less than $1 \%$ of summer values. Haage (1975) observed the lowest number of individuals at a site near Askö (Swedish Baltic Sea coast) and at a depth of $0.5 \mathrm{~m}$, during winter and spring too. The density of the animals increased during the following months.

The isopods Idotea baltica and $I$. chelipes composed an average $36 \%$ of the total biomass for the year with a maximum value of $54 \%$ in August. The month of highest abundance of Idotea individuals ( 2350 in July) is, as it is for the gammarids, one month before the largest biomass was observed ( $8.2 \mathrm{~g}$ in August). In winter ${ }_{f}$ the isopods disappeared completely from the Fucus belt. Data from Figure 4 indicate that probably

Table 2. Composition of fauna among Fucus plants (g dry weight of animals per kg Fucus dry weight) in Kiel Fjord 1978/79

\begin{tabular}{|lccccccc|}
\hline Month & $\begin{array}{c}\text { Littorina } \\
\text { spp. } \\
\text { (incl. shells) }\end{array}$ & $\begin{array}{c}\text { Mytilus } \\
\text { edulis } \\
\text { (excl. shells) }\end{array}$ & $\begin{array}{c}\text { Gamma- } \\
\text { rids }\end{array}$ & $\begin{array}{c}\text { Jaera } \\
\text { albifrons }\end{array}$ & $\begin{array}{c}\text { Idotea } \\
\text { spp. }\end{array}$ & $\begin{array}{c}\text { Chiro- } \\
\text { nomids }\end{array}$ & $\begin{array}{c}\text { Total } \\
\text { (excl. Lit- } \\
\text { torina) }\end{array}$ \\
\hline Jan & 0.1 & 0.3 & 1.1 & $<0.1$ & 0.0 & 0.0 & 1.4 \\
Feb & 0.0 & 0.0 & 0.0 & 0.0 & 0.0 & 0.0 & 0.0 \\
Mar & & & & & & & \\
Apr & 0.0 & $<0.1$ & 1.9 & 0.0 & $<0.1$ & 0.0 & 1.9 \\
May & 0.0 & $<0.1$ & 9.5 & $<0.1$ & 6.1 & 0.2 & 15.8 \\
Jun & 11.1 & 0.3 & 9.1 & 0.3 & 5.1 & 2.1 & 16.9 \\
Jul & 22.2 & 0.2 & 6.8 & $<0.1$ & 8.2 & 0.1 & 15.3 \\
Aug & 43.2 & $<0.1$ & 3.8 & $<0.1$ & 4.5 & $<0.1$ & 8.3 \\
Sep & 1.5 & $<0.1$ & 3.0 & 0.0 & 1.0 & 0.0 & 4.0 \\
Oct & 8.5 & $<0.1$ & 2.9 & 0.0 & 0.0 & 0.0 & 2.9 \\
Nov & 0.3 & $<0.1$ & 1.5 & 0.0 & 0.0 & 0.0 & 1.5 \\
Dec & 0.0 & $<0.1$ & & & & & \\
& & 1.4 & 58.2 & 0.5 & 36.2 & 3.7 & 100.0 \\
Percentage & & & & & & & \\
\hline
\end{tabular}


two reproduction periods exist - one in. June and the other in late August. In comparison, Haage (1975) found an increase in stock size of $I$. chelipes in summer and autumn, up to 2400 individuals per $\mathrm{kg}$ Fucus dry weight, while in winter he observed a big decrease.

Table 3. Composition of fauna around Fucus plants (individuals per kg Fucus dry weight) in Kiel Fjord 1978/79

\begin{tabular}{|c|c|c|c|c|c|c|c|c|}
\hline Month & $\begin{array}{c}\text { Lit- } \\
\text { torina } \\
\text { spp. }\end{array}$ & $\begin{array}{l}\text { Mytilus } \\
\text { edulis }\end{array}$ & $\begin{array}{c}\text { Poly- } \\
\text { chaetes }\end{array}$ & $\begin{array}{c}\text { Coro- } \\
\text { phium } \\
\text { spp. }\end{array}$ & $\begin{array}{l}\text { Gamma- } \\
\text { rids }\end{array}$ & $\begin{array}{l}\text { Jaera } \\
\text { albi- } \\
\text { frons }\end{array}$ & $\begin{array}{l}\text { Idotea } \\
\text { spp. }\end{array}$ & $\begin{array}{l}\text { Chiro- } \\
\text { nomids }\end{array}$ \\
\hline Jan & 4 & 34 & 0 & 0 & 153 & 25 & 0 & 0 \\
\hline Feb & 0 & 0 & 0 & 0 & 12 & 46 & 0 & 0 \\
\hline \multicolumn{9}{|l|}{ Mar } \\
\hline Apr & & & & & & & & \\
\hline May & 1 & 5 & 26 & 0 & 469 & 1 & 12 & 0 \\
\hline Jun & 42 & 41 & 61 & 53 & 15239 & 505 & 1355 & 1097 \\
\hline Jul & 535 & 151 & 36 & 66 & 25409 & 5816 & 2347 & 18739 \\
\hline Aug & 227 & 130 & 15 & 3 & 9065 & 698 & 2103 & 474 \\
\hline Sep & 65 & 20 & 0 & 0 & 1447 & 53 & 598 & 23 \\
\hline Oct & 62 & 39 & 0 & 0 & 441 & 17 & 102 & 0 \\
\hline Nov & 18 & 49 & 0 & 0 & 358 & 22 & 4 & 0 \\
\hline Dec & 0 & 45 & 0 & 0 & 245 & 13 & 0 & 0 \\
\hline
\end{tabular}

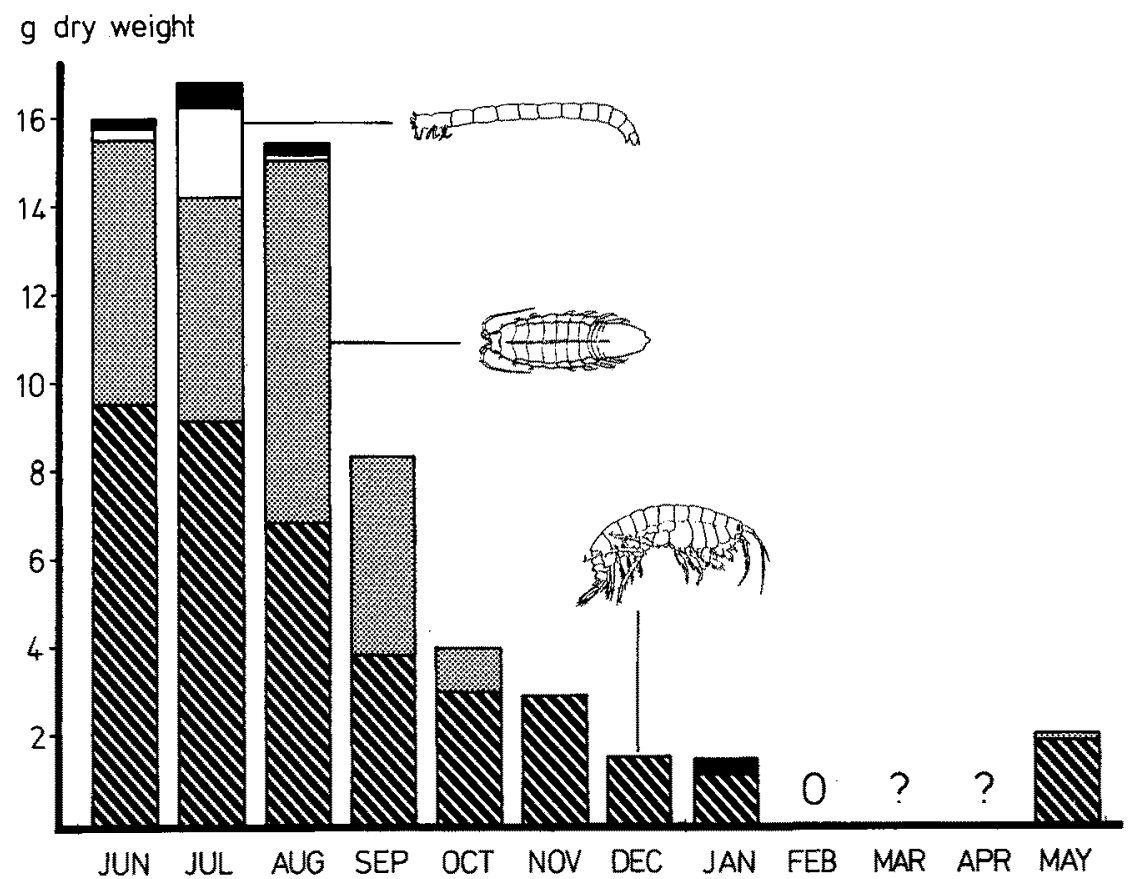

Fig. 2. Seasonal fluctuations in macrobenthos among Fucus plants (per kg dry weight) in Kiel Fjord (western Baltic Sea): gammarids, Idotea spp., chironomids, and others (black bars) Littorina spp. not considered. The low value in May is attributable to the harsh conditions in the winter of $1978 / 79$ 
Besides gammarids and Idotea, all other inhabitants contributed, on an axerage, only $5.6 \%$ to the total annual biomass (Table 2, Fig. 2). The gastropod genus Littorina has been excluded from these calculations, as it usually does not serve as fish food, due to its thick shell. For Littorina, one single spatfall in late July was observed (Fig. 4).

Chironomid larvae were common during summer. Their maximum occurrence, 18700 individuals and $2.1 \mathrm{~g}$ biomass, was found in July. This represented $12 \%$ of the total biomass (Table 2). From October to May they were missing.

Up to 5800 individuals of the isopod Jaera albifrons were present in July. This period of maximum production is in accordance with the findings of Schütz (1969) in the mesohaline area of the Kiel Canal. There seemed to be only one reproduction period in 1978, the "spring generation". Due to their small size, their contribution to the total biomass was negligible.

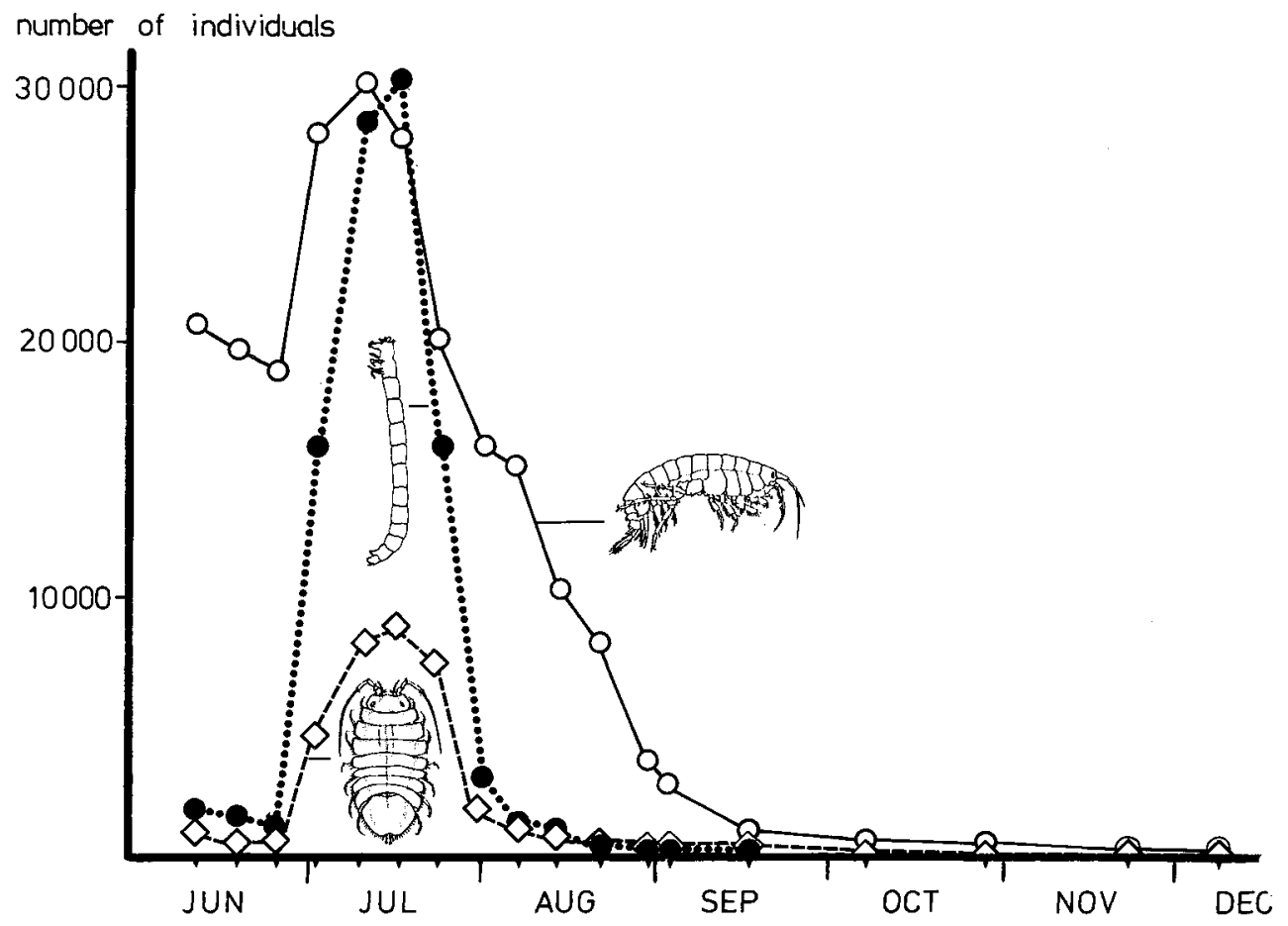

Fig. 3. Seasonal fluctuations in the abundance of the three most numerous macrobenthic species among Fucus plants (per kg dry weight) in Kiel Fjord (1978): gammarids, chironomids, and Jaera albifrons

Occasional species found in the samples were Lucernaria quadricornis, Hydrobia sp., Mytilus edulis, Cardium edule, various polychaete species, Gastrosaccus spinifer, Mysis mixta, Corophium sp., Crangon crangon, and Carcinus maenas.

For all groups listed in Table 3, July was the month of greatest density of individuals. Accordingly, one single period of reproduction seems to exist. The genus Idotea may be an exception, probably due to the existence of two species which were not separated during this survey. 


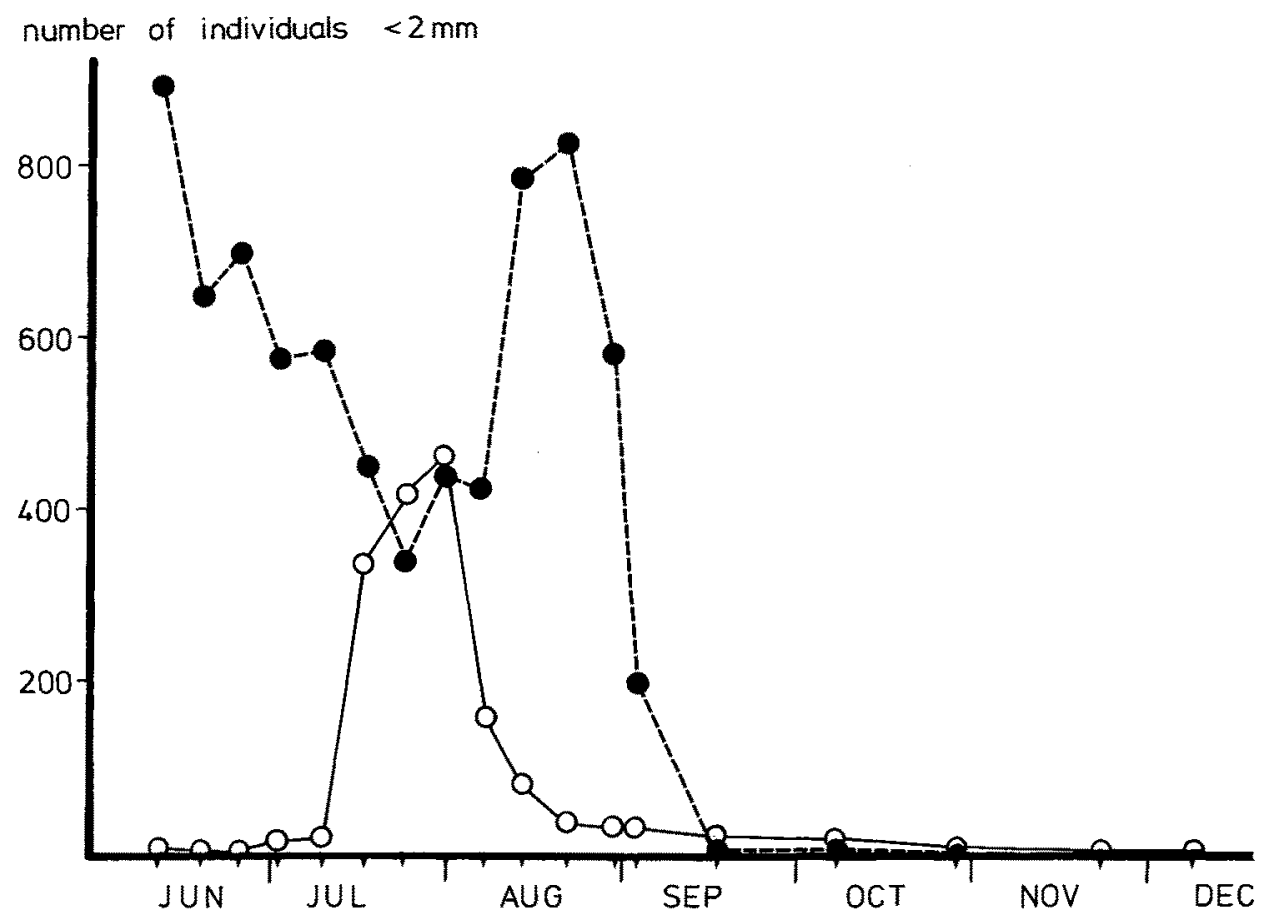

Fig. 4. Spatfall of Littorina spp. (unbroken line) and Idotea spp. (broken line) among Fucus plants (per kg dry weight) in Kiel Fjord (1978)

The maximum biomass of all groups occurred between June and August. The total biomass increased from $1.9 \mathrm{~g}$ in May to $15.8 \mathrm{~g}$ in June and reached a peak of $16.9 \mathrm{~g}$ in July. A $50 \%$ reduction in weight occurred from August to September and again in October. The average weight from December to February was only $1 \mathrm{~g}$. These seasonal fluctuations of zoobenthos in the Fucus belt correspond largely to the seasonal fluctuations of the fish fauna in the same area, which will be the subject of an additional study.

\section{LITERATURE CITED}

Boaden, P. J. S., O'Connor, R. J. \& Seed, R., 1975. The composition and zonation of a Fucus serratus community in Strangford Lough, Co. Down. - J. exp. mar. Biol. Ecol. 17, 111-136.

Haage, P., 1975. Quantitative investigations of the Baltic Fucus belt macrofauna. 2. Quantitative seasonal fluctuations. - Contr. Askö Lab. Univ. Stockholm 9, 1-88.

Haage, P., 1976. Quantitative investigations of the Baltic Fucus belt macrofauna. 3. Seasonal variation in biomass, reproduction and population dynamics of the dominant taxa. - Contr. Askö Lab. Univ. Stockholm 10,1-84.

Haage, P. \& Jansson, B.-O., 1970. Quantitative investigations of the Baltic Fucus belt macrofauna. 1. Quantitative methods. - Ophelia 8, 187-195.

Hagerman, L., 1966. The macro- and microfauna associated with Fucus serratus L. with some ecological remarks. - Ophelia 3, 1-42.

Hoffmann, C., 1952. Über das Vorkommen und die Menge industriell verwertbarer Algen an der Ostseeküste Schleswig-Holsteins. - Kieler Meeresforsch. 9, 5-14. 
Knight, M. \& Parke, M., 1950. A biological study of Fucus vesiculosus L. and Fucus serratus L. J. mar, biol. Ass. U. K. 29, 439-515.

Oertzen, J. A. von, 1968. Untersuchungen über die Besiedlung der Fucusvegetation der Gewässer um Hiddensee. - Z. Fisch. 16, 253-277.

Ohm, G., 1964. Die Besiedlung der Fucus-Zone der Kieler Bucht und der westlichen Ostsee unter besonderer Berücksichtigung der Mikrofauna. - Kieler Meeresforsch. 20, 30-64.

Schütz, L., 1969. Okologische Untersuchungen über die Benthosfauna im Nordostseekanal. III. Autökologie der vagilen und hemisessilen Arten im Bewuchs der Pfăhle: Makrofauna. - Int. Revue ges. Hydrobiol. 54, 553-592.

Segerstråle, S. G., 1928. Quantitative Studien über den Tierbestand der Fucus-Vegetation in den Schären von Pellinge (an der Südküste Finnlands). - Commentat, biol. 3 (2), 1-14.

Segerstråle, S. G., 1944. Weitere Studien über die Tierwelt der Fucus-Vegetation an der Südküste Finnlands. - Commentat. biol. 9 (4), 1-28.

Skult, P., 1977. Composition of phytal macrofauna communities on transects extending seaward from Helsinki. - Mem. Soc. Fauna Flora fenn. 53, 43-56. 